\title{
Cooperative Learning Model in Tilawati Al Quran to Cultivate Student Characters: Multi-Case Study
}

\author{
${ }^{*}$ U Jaeni ${ }^{1}$, I Basuki ${ }^{1}$, Moedjiarto ${ }^{1}$ \\ 1Department of Management, Universitas Negeri Surabaya, Surabaya Indonesia
}

\begin{tabular}{l}
\hline Article Info \\
\hline Article history: \\
Received November 17, 2020 \\
Revised December 13, 2020 \\
Accepted December 26, 2020 \\
Available Online December 28, \\
2020 \\
\hline
\end{tabular}

Keywords:

Cooperative Learning Models

Multi Case Studies

Tilawati Al-Qur'an

\begin{abstract}
Education needs a generation that understands and is aware of a superior character culture. This study aims to analyze 25 student characters' development process in cooperative learning in Al-Quran tilawati at Junior High School Al Muslim of Sidoarjo, Islamic Junior High School of 1 Surabaya, and Junior High School of 34 Surabaya. This research method uses qualitative research. This type of research uses a multi-case study from three school places. The sample of this research is the principal, the coordinator of the Al Quran teaching model, the teacher of Al Quran, the teacher of Al Quran learning model of the tilawati model and the students and by using research instruments, namely observation (observation), interview (interview), questionnaire (questionnaire), documentation and the combination of the four or triangulation. Based on the research conducted, it was found that the process of growing 25 characters in learning Al Quran with the tilawati model at Junior High School Al Muslim of Sidoarjo, Islamic Junior High School of 1 Surabaya, and Junior High School of 34 Surabaya gave good and strong results and obtained the growth of 25 character attitudes, namely respect for teachers, discipline, courageous and caring for others, orderly, compassionate, tolerant, love of Allah, spirit of learning to study, focus, spirit, patient, tolerant, obedient, togetherness, fond of reading, hard work, curiosity, caring, democracy, love of peace, neat in clothes, thorough, tawakkal, brave, independent, unyielding, and creative.
\end{abstract}

\section{INTRODUCTION}

Education is a scientific gateway that provides a decisive role and contribution to a country (Sulaiman \& Wibowo 2016; Quan et al., 2013) because it includes basic human needs (Lemke \& Johnsin, 2013). Improving the quality of education can be seen from professional educational resources (Firestone et al., 2020; Cheung et al., 2011). Being a professional teacher and having a good work ethic in delivering every learning material is an essential factor in student learning outcomes (Jennifer et al., 2017; Antonia et al., 2020). The success in conveying the material preparing teaching materials (Efendi et al. 2020) and knowledge that is owned is the basis for the success of a teacher, but a teacher must also be able to cultivate and cultivate a good character in students, both outside learning and in learning (Barus \& Munkasi, 2019; Deswati et al., 2020; Umi et al., 2018; Sofian, 2018). Education is used as an initial milestone in preparing exemplary character (Fokhmana et al., 2017). After all, it must experience improvement (Barus \& Munkasi, 2019; Rokhman et al., 2014). Education becomes the center of scientific success and exemplary character.

Indonesian National Education has the goal of achieving education that not only produces students who are smart and have expertise in certain fields, but education also demands that 
students be able to develop skills both in attitude and in character (Barus \& Munkasi, 2019). However, students have characters that are not of the same type, but different (Kane et al., 2017; Aqib \& Sujak, 2011). Skills in knowledge without mastery of skills and character accompanied by a strong level of faith are useless (Ikhwan, 2014). Because morals are important in education (Malik et al., 2015; Setiawan, 2020). Nowadays, the role of spiritualists and the role of religion in promoting morality also really needs to be considered (Fuad, 2014). The development that needs to be owned by everyone, both students and educators, is the development of morals, morals, and personal character (Ikhwan, 2014). Therefore, character development from an early age in school is mandatory to be taught and preserved. Starting from courtesy and good speech (Kane et al., 2017; Fua et al., 2018; Utomo \& Juul, 2017). A complete understanding of the importance of superior character both in attitude and speaking will provide comfort in social and educational environments (Che Noh et al., 2019).

In this industrial era 4.0, character building in students is not only applied to Islamic religious subjects, but also all subjects in the classroom. However, it remains that Islamic religious education has a very important role in fostering and developing the character and morals of students (Anwar et al., 2018). The basic basis for applying the attitudes and character values of students in Islam is clearly stated in the religious scriptures, especially Islam (Hakim, 2014; Mubarok et al., 2020). In teaching religious education, it is also contained by providing delivery including reading, interpreting, and interpreting the meaning of the Al-Qur'an (Khannah \& Waqfin, 2019). Through character culture through the tilawati learning model will be able to lead students to develop good self-character (Othman et al., 2017; Dalmeri, 2014). Based on this background, this study discusses how the process of developing student character in learning the Al-Qur'an tilawati model at Junior High School Al Muslim of Sidoarjo, Islamic Junior High School of 1 Surabaya, and Junior High School of 34 Surabaya.

\section{RESEARCH METHOD}

\section{General Background}

This research uses qualitative research. This type of research uses a multi-case study from three schools, namely at Junior High School Al Muslim of Sidoarjo, Islamic Junior High School of 1 Surabaya, and Junior High School of 34 Surabaya. A multi-case case study is to explain case study research is in-depth research to get an understanding of an individual, group, or situation regarding its meaning, process, and understanding (Emzir, 2018). It is said in depth because case study research wants to answer the question of why and how a phenomenon or event takes place.

\section{Sample/Participant}

Research subjects are people who will be asked for information or people who become sources of information in research. The subjects in this study were the principal of the school, the coordinator of the Al-Quran teaching model, the teacher of the Al-Quran, the supervisor of the Al-Quran learning model, and the students. The population of this study is all school management leaders in the organizational structure of the three Junior High School places mentioned above. The sampling process used purposive sampling and snowball sampling. Using purposive sampling because in sampling some considerations are needed first. Then using snowball sampling to take a sampling technique that needs to be small, over time becomes large. This is done because the subject of data source that has been determined since the beginning has not provided complete data. So if the school principal, Al Quran teaching teacher, Tilawati model Al Quran learning supervisor and students are not able to provide complete data, information or research subjects will be added with people who can provide more complete data, which is still included in the population category.

\section{Instrument and Procedures}

Sources of data in this study include two things, namely humans and non-humans. Human data sources consist of principals, teachers, supervisors, and students. Meanwhile, non-human data sources consist of documents that support the research focus. The research instrument was 
carried out using observation (observation), interview (interview), questionnaire (questionnaire), documentation, and a combination of the four or triangulation. The research procedure was carried out in three stages as a flowchart as follows:

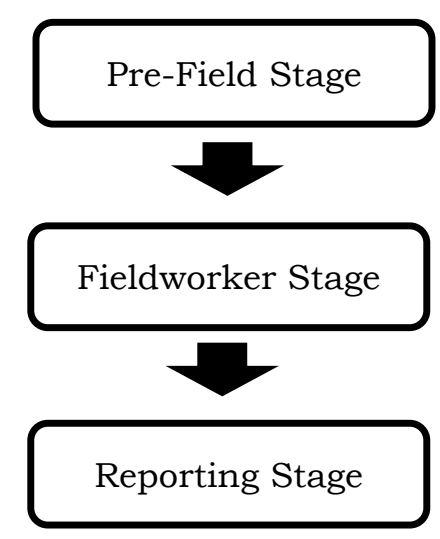

Figure 1. Three Stages procedure of research

The research procedure was carried out in several stages, namely the pre-field stage, the fieldworker stage, and the reporting stage. The researcher conducted a preliminary study of the school which was planned to be the object of the research site. The first stage is the pre-field stage by conducting a preliminary study to obtain an overview of how the school can provide solutions and answer the problems that the researcher is thinking about. Next, the researcher digs from various sources of literature study that are relevant to the problem being designed to strengthen the theoretical foundation as a research base. Second, the fieldwork stage is data mining activity, data mining is carried out using observation, interviews, and documentation study. The third stage, the Reporting Stage, is the final result of the research that will be used as a basis and communicated so that the research carried out can be used as a reference in solving commensurate problems.

\section{Data Analysis}

The data analysis of this research begins with the process of collecting data by the information from the research subjects. Continued after the data is obtained by research then each data selection process is called condensation. Then the process of checking the data and ends with concluding the three data in the three schools. After the three data from the school were obtained, they were analyzed using single data and cross-case data.

\section{RESULT AND DISCUSSION}

The culture of learning management in the Qur'an. The tilawati model to foster student character by using multi-case studies from three schools resulted in a fairly good contribution in fostering student character. This is contained in previous research (Umar et al., 2020). Learning management, the tilawati learning process in the three schools, namely at Junior High School Al Muslim of Sidoarjo, Islamic Junior High School of 1 Surabaya, and Junior High School of 34 Surabaya have resulted in very precise learning management principles (Umar et al., 2020). Then through further research on the 25 character growth syntax in the Qur'anic learning model of the tilawati will be explained further in this research article. In this study, the results of the growth of 25 characters will be analyzed through the syntax of the learning process.

To foster student character through learning the Al-Quran model of tilawati at Junior High School Al Muslim of Sidoarjo, Islamic Junior High School of 1 Surabaya, and Junior High School of 34 Surabaya, the three schools use a method of designing a learning process with a syntax that is arranged based on the stages of learning. In line with Thomas (1991), there are two ways to instill character, namely through the curriculum according to the content of the subject matter and through the learning process. One of the learning models that can foster character values is the cooperative model (Thomas, 1991). Sukmadinata (2005) states that there are two approaches 
to teaching implementation, namely the learning outcomes approach and the process approach. Good learning outcomes are generated by a good learning process.

To find out how the development of 25 characters through the learning process of the Qur'an, the model of tilawati observational data mining research is focused on three stages of learning steps which include (a) the class preparation stage, (b) the learning process, (c) learning closure and (d) learning evaluation.

\section{Character Development Syntax in Cooperative Learning Al Quran Model Tilawati at Junior High School Al Muslim of Sidoarjo Class Preparation}

Class preparation is an activity carried out by students before the implementation of the learning process begins. Activities carried out by students can be informed, namely before starting to learn the students together go to a place of study. There are two class groups this semester that will enter the advanced class or Al Quran tadarrus class. The place to study is outside the main building, namely in the gazebo located in front of the building. After arriving at the gazebo, the students shook hands with the teacher then cleaned the seats together. Then the students sat in a circle in a circle forming an $\mathrm{O}$ and the teacher sat in the same format and connected in a circle. After sitting perfectly neatly, the students took out the Quran muskhaf as a learning medium. All activities carried out by students are always observed by the teacher who guides the group.

It appears that this learning class preparation activity fosters several student characters, namely: 1) Respect for the teacher, which is shown by getting used to shaking hands with the teacher before starting learning with a tawadduk attitude. 2) Affection, which is shown by the togetherness in the group when heading to the study area and a patient attitude when taking turns occupying a seat. 3) Tolerant, which is shown by students that they can get along without favoritism. They are familiar with the grouping of tilawati Al Quran study classes, where students come from different subject classes, some from class VII a class VII b, and so on. The grouping of tilawati classes is based on mastery of reading Al-Quran, not by grade level in general subjects. 4) cooperation, which is shown by jointly preparing and cleaning the gazebo as a place for learning. 5) Independence and responsibility, which is shown by students being able to prepare their learning tools. 6) Discipline, which is shown by the students being accustomed to starting Al-Quran learning on time and accustomed to sitting up straight in an O format. With an O-letter position, all students are directly facing the teacher so it is easy to control.

\section{Learning process}

In the implementation of the learning process, the activities carried out include preliminary activities and core activities. Of the two activities based on observations, namely:

Preliminary activities

When the children were ready to learn at 11.30, the teacher started to open the learning class with greetings and prayers and continued reading the letter $\mathrm{Al}$ Fatihah. Students sit in a circular Oletter format with 7 students in one group. It appears that this preliminary or opening activity can foster student character, namely; a) Love of Allah, which is shown by earnest and hopeful prayer. b) The enthusiasm for learning to study is shown by understanding the meaning of prayer, which implies that it is facilitated to receive knowledge and hope that it becomes useful knowledge. c) Fair, indicated by sitting in a circle, all students have their turn to read fairly one by one.

\section{Core activities}

After the opening stage of learning, the teacher instructs and invites all students to open the Quran muskhaf on a page that has been determined by the lesson plan. Then the teacher invited them to read the Koran together. The children could be heard loudly reciting a very good reading. The recitation is repeated continuously guided by the Master. In the next turn, the teacher reads, then the students imitate and then the students read one verse in turn. When one student reads, the other listens and listens with full concentration. And patiently waiting for their turn to read. 
After reading it, the teacher reminds and asks the students about the law of recitation. The children repeat several times to read but the children remain in a state of focus.

It appears that the stages of the core learning activities are to foster several student characters as follows. a) Courageous and unified, which is shown courage and togetherness in reciting the lafadz of the Quran aloud without hesitation. b) Patience, which is shown by the students waiting their turn to read the verses of the Koran from one another to another while paying attention and listening to the reading which becomes their turn. c) Obey, which is shown by students obeying the rules of implementing learning from class preparation to the learning implementation process. Students want to carry out the rules that have been set in class such as being on time, cleaning and preparing a place to study, reading in turns, sitting regularly. d) Togetherness, which is shown by students working together in groups. e) Like to read, it is shown that students repeat the recitation of the Koran which is guided by the teacher until they are considered understanding and fluent. f) Hard work, shown by students reading aloud. Students always read by repeating things that are not yet fluent. g) Curiosity, shown by students listening diligently to recite or pronounce the letters of the Koran and listen to the teacher's explanation of the laws of recitation. h) Focus, which is shown by students following the learning process coherently with various techniques performed by the teacher. i) Caring, which is shown by students reminding each other when a friend misreads either a word or a wrong reading order. j) Democracy, which is shown by students having the courage to express and answer questions directly from the teacher. In answering student questions in turn. k) Tolerant, with students giving the same opportunity to answer questions.

\section{Closing study}

Closing learning is a learning stage in ending the teaching and learning process. The activities carried out in the closing stage were the teacher giving short messages containing the children so that they would often read the Al-Quran because it was the Al-Quran that would save people in the world until the afterlife. Then the teacher asked to pray. After prayer the children came out of the gazebo one by one, shaking hands with the teacher. This closing learning activity can foster character, namely tawakkal, and love of peace.

\section{Learning evaluation}

There are several kinds of learning evaluations at Junior High School of Al Muslim, including daily evaluations, quarterly evaluations, the final evaluation of basic tilawati books, evaluation of Al Quran $30 \mathrm{Juz}$ finish, and evaluation of public tests, namely evaluations conducted openly at graduation and finishing events. The researcher will present the observation data on the implementation of the evaluation of the learning outcomes of the public test. The public test is that students who have learned the Qur'an are tested in public. Meanwhile, those who acted as questioners were opened freely by the invitees who wanted to submit questions. Invitations who attended were about 1000 people. Questions are addressed to students freely. Students who get questions answer one by one submitted by the asker.

Strengthening the results of observations about the character growth of Junior High School of Al Muslim students through the learning process of the Quran with the tilawati model as conveyed by Mr. Choirul as follows.

The character of the children is directly proportional to the learning of tilawati and character development. It means that the more intensive and frequency of learning tilawati the longer the character and attitude of the children will grow. For example, the responsibility of children to learn to read with their awareness, the discipline showed to come on time, politely shown when reciting the Koran when they meet a cleric. They greeted each other and performed 5 s. That's you, sir, smile, greetings, greetings, politeness, and courtesy. Honestly, it is shown that when asked whether they have read it at the house of the Al Quran they answer yes and it is proven by connecting books. (Deputy Teacher of Al Quran tilawati). 
To foster 25 student characters in learning Al Quran tilawati at Junior High School of Al Muslim is carried out through syntax or learning stages according to predetermined stages. Each stage of learning has a role in fostering character according to the types of activities at each stage.

\section{Character Development Syntax in Cooperative Learning Al Quran Model Tilawati at Islamic Junior High School of 1 Surabaya Class Preparation}

Researchers made observations to find out how the process of learning Al-Quran with tilawati models to foster student character. Observations were made in the class III group which was taught by the teacher. From the observations, it can be presented as follows.

Classroom preparation is a preparatory activity to initiate the learning process. The activity begins shortly before students enter the class. First, the students shook hands with the Al Quran teaching teacher at the door, including spontaneously the students greeted the researcher who did not know who and what the purpose of the researcher was there. From this incident, it seems that the students are not awkward in facing other people. At exactly 6.15, all the students of volume III tilawati were ready to sit in their respective seats. The seated formation is lined up from front to back. The number of students in the Tilawati class volume III who was taught by this teacher was 22 children consisting of boys and girls. All students prepare textbooks in front of their desks. It appears that from the observations made by the researcher, this learning class preparation activity fosters several student characters, namely; 1 ) Respect for the teacher shown by getting used to shaking hands with the teacher before starting learning with a tawadduk attitude. 2) Discipline showed by students accustomed to being on time to start learning Al Quran and accustomed to sitting neatly. 3) Courageous and caring for others, which is shown by caring for the researcher who is someone else who is not familiar at all without being awkward when the students approach and shake hands. 4) Orderly which is shown by regularly shaking hands with the teacher and taking turns in class. 5) Affection shown by the togetherness in the group when heading to the study area and a patient attitude when taking turns taking seats. 6) Tolerance is shown by the students being able to mix without favoritism they are already used to the grouping of tilawati Al Quran learning classes where students come from different classes, some from class VII a class VII $b$ and so on.

The researcher's observation data above is corroborated by the explanation given by Pak Pittono as the principal as follows.

Before learning begins, the children here are accustomed to shaking hands. The way of shaking hands is a typical model that can convey the tawaddu 'character to teachers and parents. The learning model of the model with a small group of students is more handled and cared for by students, it is hoped that a sense of affection will grow. To have an independent character, children are accustomed to cleaning the classroom independently. Before entering class, the children are taught discipline by checking the neatness of their clothes. When holding the Al Quran, the children are taught the manners or procedures for holding the holy book, namely by wearing a cap and not allowed to talk much.

(W. Principal. 22 July 2019).

The data above submitted by the principal is the result of interviews conducted by researchers before carrying out observations of the implementation of the class preparation stage. The information obtained strengthens the results of observations about the implementation of class preparation for the development of student character. The student character that can be grown according to the principal's observations includes tawaddu ', compassion, independence, discipline, and neatness in a dress.

\section{Learning process}

At the opening of the preliminary stage, the teacher says greetings and then reads the opening prayer together. The prayer that is read is a prayer to open the heart so that it is easy to receive 
knowledge and can take lessons. After the prayer is continued, read the short chorus of 30 chapters guided directly by the teacher using the song rost. With a loud voice full of enthusiasm, the students recite the Quran together. In between the children reciting the Al-Quran recitation, the teacher while paying close attention to the children's reading in short, whether it is by the laws of recitation. When there is a wrong reading, the teacher asks to repeat it. In the process of this opening activity, there are character values that can be grown, namely; 1) Love to Allah is shown by praying earnestly and full of hope. 2) The enthusiasm for learning to study is shown by understanding the meaning of prayer, which implies that it is facilitated to receive knowledge and hope that it becomes useful knowledge. Good at memorizing short letters in the Koran assigned by the teacher.

\section{Closing study}

After the opening activities are finished, then continue with the core activities. At the core stage, the researcher observes the step by step taken by the teacher. The results of these observations can be presented as follows. The teacher instructs all students to open page 40 of the teenage booklet (volume III). First, the teacher explains the reading on the subject listed on page 40 . Then the teacher reads one page on page 40 while the students listen. This method is called technique 1. After technique one is finished, the teacher reads page 40 again while students are asked to imitate each letter and sentence that the teacher reads. This method is called technique 2 . Technique step one and technique two are completed, then the teacher invites students to read in turn.

The activities of the learning process at the core activity stage above, in the observations of researchers, can foster several student characters, namely a) Focus, which is shown by students being full of concentration listening to the explanation of the teacher of Zainul when explaining the subject on page 40 about breadfruit lam. b) The learning spirit, which is indicated by the students following the learning process coherently with various techniques performed by the teacher. c) Patience showed by the students waiting their turn to read between friends while paying attention, listening, and preparing the reading that will be their turn. e) Tolerant, with the students giving the same opportunity to answer questions, not getting confused when another friend reads or answers the teacher's question. f) Obedience is shown by students obeying the rules of implementing learning from class preparation to the learning implementation process. $\mathrm{g}$ ) Togetherness that is shown by students working together in groups, learning is more serious because they try to be able to go up to the grade together. $h$ ) Love to read is shown by the students repeating the recitation of the Koran which is guided by the teacher until they are considered understanding and fluent. i) Hard work, shown by students reading aloud. j) Curiosity, shown by students listening diligently to recite the letters of the Al Quran and listening to the teacher's explanations about the laws of recitation. k) Caring, which is shown by students reminding each other when a friend misreads either a word or a wrong reading order. 1) Democracy, which is shown by students having the courage to express and answer questions directly from the teacher. In answering student questions in turn. $\mathrm{m}$ ) Love of peace is shown by students who are always in togetherness when starting class, when starting learning and when ending learning.

\section{Learning evaluation}

At the time of closing the activities carried out by the teacher, namely giving a little lecture or messages for the good of students. The teacher patiently checked the clothes of students, especially those who did not wear the songkok, was warned not to forget to visit and for students whose textbooks were left behind, they had to be brought back again. Then it ends with a closing prayer, the students leave the class while shaking hands with the teacher.

This closing learning activity can foster character, namely; 1) Neat in dress, this is shown by the students always keeping neat clothes. 2) Accuracy, it is shown that the children try to be more careful with their textbooks so they don't miss anymore. 3) Tawakkal, namely the spirit to strive for the best achievement while the final result is submitted to Allah, the Almighty God through the chanting of prayer together. 


\section{Character Development Syntax in Cooperative Learning Al Quran Model Tilawati at Junior High School of 34 Surabaya \\ Preliminary activities}

In this stage, the activities carried out include (a) students after Friday prayers enter the classroom regularly while shaking hands with the teacher, (b) students prepare to learn media books in the form of opening teachings of the Al Quran and juz amma. These activities can foster characteristics, namely discipline, order, respect, compassion, and tolerance. In the opening stage of the learning activities carried out, among others (a) the teacher says greetings, (b) the teacher invites students to read prayers, (c) the teacher invites students to read the Al-Quran short letters, (d) the teacher always observes the truth of the students' reading. These activities can foster character, namely the love of Allah, the enthusiasm for learning to study, love of the holy book.

\section{Learning process}

In this stage the activities carried out include (a) the teacher asks students to open the reading book page 46 as the subject, (b) the teacher reads each line on one page, students are asked to imitate, (c) the teacher instructs students to pay attention to the lines being read, (d) the teacher orders one page to read together, (e) then the teacher instructs the students to open the reading book on the next page, namely page 47 then explains the subject matter of the page, (f) the teacher reads one line-one line, the students mimic until one page, $(\mathrm{g})$ then the teacher instructs the students to read together, (h) the teacher asks students to reopen the reading book on page 46, (i) the teacher asks students to read one by one in turns. Other students who have not had their turn to read are asked to pay attention to their friends who are reading, (j) the teacher asks students to help correct their friends 'reading if there is a reading that is wrong and not fluent, $(\mathrm{k})$ the teacher is always around watching the students' reading while correcting if something is wrong, (l) the teacher always dynamizes the class when it is seen that the students have begun to lack concentration, and (m) all reading is voiced by the students firmly and loudly accompanied by a song called the rost song. Various activities at this core learning stage can foster student character, namely focus, enthusiasm for learning, patience, obedience, togetherness, love to read, hard work, curiosity, care, democracy, and love of peace.

\section{Closing study}

In this stage, the activities carried out include (a) the teacher provides lectures or messages of kindness to students. Namely, so that students at home always read the Koran so that their lives are guided, (b) the teacher invites prayer, and students leave the classroom while shaking hands with the teacher. This activity can foster character, namely patience, thoroughness, tawakkal, and getting used to shaking hands.

\section{Learning evaluation}

At this stage, the activities carried out include (a) the students take a volume-up test at the end of each semester, and (b) the students face a teacher who is specially assigned from another institution. These activities can foster character, namely Courage, Independence, Never give up, Creative and Confidence, and Empathy.

The researcher's observation data above was corroborated by the explanation given by Tutik Ana as the teacher who taught that during the learning process the character development of students occurred, namely as follows.

The courage shown by the students was brave to advance to the examiner's table. The independence shown by the students had to fight for themselves to pass well. Never give up, which is shown by students who have tried their best but if they don't pass, they have to repeat to take the next exam. Creativity is shown by the students looking for various ways and tips to perform well by repeating their learning methods and trying to master their mental calm so as not to feel nervous.

(Deputy Teacher of Al Quran tilawati).

Teacher Nihaya reinforces the learning evaluation activities in fostering character as follows. 
With the implementation of the final semester exams, the children's character will be able to foster self-confidence, empathy, courage, independence, unyieldingness, and creativity.

(Deputy teacher of basic tilawati).

From the data submitted by Ms. Tutik Ana and Ms. Nihaya, information can be obtained that the activity of evaluating the Al Quran tilawati learning as part of the learning process can foster student character, including courage, independence, unyielding, creative, self-confident and empathetic. The evaluation stage, includes (a) students take an up-volume test at the end of each semester, and (b) students face an assignment from another institution. These activities can foster character, namely courage, independence, unyielding, creativity, self-confidence, and empathy.

\section{The steps of learning the Quran with the recitation model to foster the character of students in} the three schools

From the analysis of the three schools above regarding the learning process that fosters several student characters, then based on observations from each stage the data is obtained in Table 1 as follows:

Table 1. Syntax / Steps of Learning Al Quran With Recitation Model to Develop Student Character

\begin{tabular}{|c|c|c|}
\hline Step & Teacher and Student Activities & $\begin{array}{l}\text { Character values that } \\
\text { are grown }\end{array}$ \\
\hline $\begin{array}{c}\text { I } \\
\text { Class } \\
\text { preparation }\end{array}$ & $\begin{array}{l}\text { (a) students shake hands with the teacher, (b) } \\
\text { students arrange to sit in a circular formation or } \\
\text { line up from front to back neatly, (c) students } \\
\text { prepare to learn media books, and (d) students sit } \\
\text { with full concentration ready to receive lessons. }\end{array}$ & $\begin{array}{l}\text { 1. Respect for the } \\
\text { teacher. } \\
\text { 2. Discipline. } \\
\text { 3. Be brave and care } \\
\text { for othersTertib } \\
\text { 4. Affection } \\
\text { 5. Tolerant }\end{array}$ \\
\hline $\begin{array}{c}\text { II } \\
\text { preliminary }\end{array}$ & $\begin{array}{l}\text { (a) the teacher says greetings, (b) the students read } \\
\text { prayers together to start learning to gain useful } \\
\text { knowledge and open their hearts to easily accept } \\
\text { knowledge, (c) students read the letters of the } \\
\text { Koran together, and (d) students simultaneously } \\
\text { read the Quran short letters in a firm and loud } \\
\text { voice. }\end{array}$ & $\begin{array}{l}\text { 1. Love to Allah } \\
\text { 2. Spirit for learning } \\
\text { to study }\end{array}$ \\
\hline $\begin{array}{c}\text { III } \\
\text { The essence } \\
\text { of learning }\end{array}$ & $\begin{array}{l}\text { (a) the teacher instructs students to open the } \\
\text { tilawati book according to the subject matter, (b) } \\
\text { the teacher explains the subject matter of the } \\
\text { predetermined pages, (c) the teacher reads one } \\
\text { page of the student listens, (d) the teacher reads the } \\
\text { same page the student imitates, (e) the teacher } \\
\text { orders them to read and listen in turns, that is, one } \\
\text { student reads the other listening. This is done in } \\
\text { turns, (f) when a student reads another student } \\
\text { listens while paying attention if there is something } \\
\text { wrong to remind and correct each other, and (g) } \\
\text { the teacher always pays attention to and motivates } \\
\text { students to always concentrate, and (h) the teacher } \\
\text { pays attention to rote reading Al Quran short } \\
\text { letters. In each reading, the students sing a song } \\
\text { with the same rhythm called the roost song with a } \\
\text { loud voice. }\end{array}$ & $\begin{array}{ll}\text { 1. } & \text { Focus. } \\
\text { 2. Spirit } \\
\text { 3. } \\
\text { 4. } \text { Be patient } \\
\text { 5. Obey } \\
\text { 6. Togetherness } \\
\text { 7. Love to read } \\
\text { 8. Hard work, } \\
\text { 9. Curiosity, } \\
\text { 10. Care, } \\
\text { 11. Democracy, } \\
\text { 12. Love peace }\end{array}$ \\
\hline IV & $\begin{array}{l}\text { (a) the teacher gives a little tausiyah or messages of } \\
\text { goodness values to students, (b) the teacher checks }\end{array}$ & $\begin{array}{l}\text { 1. Neat in dress } \\
\text { 2. Accuracy }\end{array}$ \\
\hline
\end{tabular}




\begin{tabular}{|c|c|c|}
\hline Step & Teacher and Student Activities & $\begin{array}{c}\text { Character values that } \\
\text { are grown }\end{array}$ \\
\hline $\begin{array}{l}\text { Closing of } \\
\text { Learning }\end{array}$ & $\begin{array}{l}\text { the neatness of the students' clothes, and (c) the } \\
\text { teacher ends with a prayer, and }(\mathrm{d}) \text { the students } \\
\text { leave the classroom shaking hands with the } \\
\text { teacher. }\end{array}$ & 3. Resignation. \\
\hline $\begin{array}{c}\mathrm{V} \\
\text { Evaluation }\end{array}$ & $\begin{array}{l}\text { (a) students at the end of each lesson take the } \\
\text { volume increase test, (b) students who pass can } \\
\text { move up the volume level above it, and the } \\
\text { finished exam is } 30 \text { juz, and there is a public test (c) } \\
\text { students take the exam by facing different } \\
\text { examiners. }\end{array}$ & $\begin{array}{ll}\text { 1. } & \text { Be brave. } \\
\text { 2. Independence. } \\
\text { 3. Never give up. } \\
\text { 4. Creative. }\end{array}$ \\
\hline
\end{tabular}

It appears that from the activities of the learning process with the syntax or stages carried out by the teacher and students in the table above that the learning of the Quran in the model of tilawati is equally active. Student active teachers are also active. The teachers used a mixed learning approach between teacher-centered approaches and student-centered approaches. In this approach, it appears that the teacher is actively guiding by giving examples of how to read the Koran correctly with the strategies and techniques that have been prepared. Meanwhile, students are assigned the assignment to listen, imitate, listen, experience, and contribute suggestions to other friends if a friend is wrong. Students are also given personal responsibility by memorizing some verses from the Al Quran. Students take responsibility for the success of their study groups. Because the increase in pages in tilawati book volumes depends on that achievement. This is by the provisions set out in the tilawati learning strategy as stated by Hasan, et al., (2010) that the increase in tilawati volumes is based on the results of daily evaluations carried out by the teacher. The volume of students will be increased if 70 percent of the reading is fluent and vice versa if students in one group are less than 70 percent then they cannot move up the grade. thus all students are responsible for the achievement of their group. . In this case it is by research from Thoha (2018) that in cooperative learning students will be able to be responsible for their personal and group assignments and be able to be motivated and active in classroom learning.

Teachers and students are both active. Meanwhile, learning activities use the cooperative model of learning theory by being modified or developed according to the needs and circumstances. The longer the time allocated for the process of education and learning Al Quran tilawati, the cultivation of character will give stronger results. Supported by Arifin's research, (2019) states that through cooperative learning, students can increase their tajwid mastery. Education as an effort to cultivate habituation requires a long time with a tiered program. Based on each learning process that has been carried out by the three schools, namely Junior High School Al Muslim of Sidoarjo, Islamic Junior High School of 1 Surabaya, and Junior High School of 34 Surabaya, 25 characters are grown by students. This character development is not only caused during the learning process but has been applied outside of learning hours, as is the habit of students before learning begins. The process of growing 25 characters in the tilawati model of Al-Quran learning at Junior High School Al Muslim of Sidoarjo, Islamic Junior High School of 1 Surabaya, and Junior High School of 34 Surabaya gave good and strong results. The success of the learning process cannot be separated from the learning process taking place. In each stage of the learning process that has been designed with good character culture, students will get a good attitude (Khannah \& Waqfin, 2019). Research by Umar et al., (2020) states that the culture of learning Al-Quran with the tilawati model makes a good contribution to fostering student character. Then the principles of Al-Qur'an learning management that have been applied are very precise (Umar et al., 2020).

From the results of the tilawati model of Al-Qur'an learning culture at Junior High School Al Muslim of Sidoarjo, Islamic Junior High School of 1 Surabaya, and Junior High School of 34 
Surabaya, it was obtained the development of 25 character attitudes, namely respect for teachers, discipline, courage, and care for others, orderly, compassion. , tolerant, love of Allah, the spirit of learning, focus, spirit, patient, tolerant, obedient, togetherness, fond of reading, hard work, curiosity, care, democracy, peace-loving, neat in clothes, thoroughness, tawakkal, courageous, independent, unyielding, and creative. This is by the research of Ikhwan et al., (2019) that when the learning process is structured with good culture, it will produce students with character.

\section{CONCLUSION}

Based on the process of growing 25 characters in the tilawati model of Al-Quran learning at Junior High School Al Muslim of Sidoarjo, Islamic Junior High School of 1 Surabaya, and Junior High School of 34 Surabaya gave excellent and robust results. From the results of the tilawati model of Al-Qur'an learning culture at Junior High School Al Muslim of Sidoarjo, Islamic Junior High School of 1 Surabaya, and Junior High School of 34 Surabaya, it was obtained the development of 25 character attitudes, namely respect for teachers, discipline, courage, and care for others, orderly, compassion. , tolerant, love of Allah, the spirit of learning, focus, spirit, patient, tolerant, obedient, togetherness, fond of reading, hard work, curiosity, care, democracy, peace-loving, neat in clothes, thoroughness, tawakkal, courageous, independent, unyielding, and creative. This research can contribute to scientific development in the fields of policy, education management, learning management, and character building through teaching and learning activities. The limitation of this research is carried out at the junior high school level to implement future research implementation. Further trials are needed at the school level below or above, which have different conditions and environments.

\section{ACKNOWLEDGEMENTS}

The author would like to thank all leaders at the Faculty of Education Management, Surabaya State University, and all leaders and fellow teachers at Junior High School Al Muslim of Sidoarjo, Islamic Junior High School of 1 Surabaya and Junior High School of 34 Surabaya who have helped in the success of this research.

\section{REFERENCES}

Adawiah, R. (2018). Instilling the environmental care characters to the elementary schools located on the rivers banks. Journal of Wetlands Environmental Management 6(1), 84-92.

Antonia, M., Lamers, R., Wilfried, F., Admiraal., \& Roeland, M. (2020). Expatriate academics and transnational teaching: the need for quality assurance and quality enhancement to go hand in hand. Higher Education Research \& Development, 39(4), 733-747.

Anwar, C., Saregar, A., Hasanah, U., \& Widayanti, W. (2018). The effectiveness of islamic religious education in the universities: The effects on the students' characters in the era of industry 4.0. Jurnal Keguruan dan Ilmu Tarbiyah, 3(1). 77-87.

Aqib, Z., \& Sujak, (2011). Panduan \& aplikasi pendidikan karakter. Yrama Widya.

Arifin, A. (2019). Efektivitas model pembelajaran kooperatif stad menggunakan alat peraga AlQur'an untuk meningkatkan penguasaan tajwid. Jurnal Pendidikan Agama Islam, 17(2), 189201.

Barus, G., \& Mungkasi, S. (2019). On the publication of research papers in the area of character education. International Journal of Mechanical Engineering and Technology, 10(3), 1630-1635.

Che-Noh, M. A., Kasan, H., Yusak, Y.M., \& Yusuf, S.A.M. (2019). Strategic management of Qur'anic recitation teaching among primary school teachers in Malaysia. Journal of Islamic Education, 3(1), 1-8.

Cheung, W. C., \& Hew, K. F. (2011). Design and evaluation of two blended learning approaches: Lessons learned. Australian Journal of Educational Technology, 8, 1319-1337. 
Dalmeri. (2014). Pendidikan untuk pengembangan karakter, telaah terhadap gagasan Thomas Lickona dalam educating for character. Jurnal Al-Ulum IAIN Sultan Amai Gorontalo, 14(14), 269-288.

Deswati, Suwondo, \& Firdaus L. N. (2020). Student growth of care characters of students' environment in the lisambil discussion in SMP Negeri 21 Pekanbaru. Journal of Educational Sciences, 4(1), 93-105.

Efendi, M. Y., Cheng, T.-H., Sa' diyah, E. H., Wulandari, D., Qosyim, A., \& Suprapto, N. (2020). Study of the Implementation of Socratic Dialogue at History of Physics Course. Studies in Philosophy of Science and Education, 1(1), 7-20.

Emzir. (2018). Metodologi penelitian kualitatif analisis data. Raja Grafindo Pustaka.

Faud, M. (2014). Agama dan pendidikan karakter: Pengembangan keilmuan dan kompetensi program studi pada UIN Sunan Kalijaga Yogyakarta. Jurnal Pendidikan Agama Islam, 9(2), 149168.

Firestone, A. R., Rebecca, A., Cruz., \& Janelle, E. (2020). Teacher study groups: An integrative literature synthesis. Review of Educational Research, 90(5), 675- 709.

Fua, J. L., Rahma., Nurlila, R. U., \& Wekke, I. S. (2018). Strategy of islamic education in developing character building of environmental students in Indonesia. Earth and Environmental Science, 175, 1-6.

Hakim, R. (2014). Pembentukan karakter peserta didik melalui pendidikan berbasis Al Quran. Jurnal Pendidikan Karakter, 4(2), 123-136.

Hasan, A., Arif, M., Rouf, A. (2010). Panduan praktis penerapan kurikulum pembelajaran Al Quran. Surabaya: Nurul Falah.

Ikhwan, A. (2014). Integrasi pendidikan islami (Nilai-Nilai islami dalam pembelajaran), Jurnal Pendidikan Islam, 2(2), 179-194.

Ikhwan. A., Ju'subaidi., \& Rohmad, A. (2019). Development of curriculum keaswajaan (Nahdlatul 'Ulama) in character formation: In global perspectives on teaching and learning paths in islamic education. IGI Global, 1(1), 92-117.

Jaeni, U., Basuki, I., \& Moedjiarto. (2020). Culture learning management Al-Qur'an model tilawati to improve student character. International Journal of Recent Educational Education, 1(3), 286300.

Jennifer, G., Adam. L., Maxwell, S., Julie, B., Hywel, E., \& David, L. (2017). Effects of professional development on the quality of teaching: Results from randomised controlled trial of quality teaching rounds. Teaching and Teacher Education, 68, 99-113.

Kane, M., Frauke, M., Esther, S. Y., Christine, M., \& Rubie, D. (2017). Subjectivity of teacher judgments: Exploring student characteristics that influence teacher judgments of student ability. Teaching and Teacher Education, 65, 48-60.

Khannah, S. N., \& Waqfin, M. S. I. (2019). Penerapan metode tilawati dalam pembelajaran AlQur'an dan kemampuan baca Al-Quran santri di TPQ Darussalam Kepanjen Jombang. Journal of Education and Management Studies, 2(6), 1-6.

Lemke-Westcott, T., \& Johnson, B. (2013). When culture and learning styles matter: A Canadian university with Middle-Eastern students. Journal of Research in International Education, 12(1), 66-84.

Thomas, L. (1991). Educating for character how our schools can teach respect and resposibilty. Bantam.

Lyer, R. B. (2017). Value-based education: Professional development vital towards effective integration. Journal of Research \& Method in Education, 1(1), 17-20. 
Malik. M., Rahim. R., Bactiar, N., \& Fahmy, R. (2015). Measuring student perception to personal characters building in education: An Indonesia case In implemetating new curiculum in high school. Science Direct Procedia-Social and Behavioral Sciences, 211, 851-858.

Mubarok, H., Safitri, N. S., \& Adam , A. S. (2020). The novelty of religion and art: Should we combine with STEM education?. Studies in Philosophy of Science and Education, 1(3), 97-103.

Ni'mah, K., \& Ashoumi, H. (2019). Strategi Peningkatan prestasi belajar nahwu kelas II Ula di Madrasah Diniyah pondok pesantren Putri Al-Lathifiyyah 1 Bahrul 'Ulum. Journal of Education and Management Studies, 2(5), 55-58.

Othman, A., Hussien, S., Ahmad, I. S., Rashid, A. A., \& Badzis, M. (2017). Islamic integrated education system model in the Malay archipelago: Implications for educational leadership. Intellectual Discourse, 25(1), 203-226.

Quan, R., Smailes, J., \& Fraser, W. (2013). The transition experiences of direct entrants from overseas higher education partners into UK universities. Teaching in Higher Education, 18(4), 414-426.

Rokhman, F., Hum, M., \& Syifudin, A. (2014). Character education for golden generation 2045. Procedia - Social and Behavioral Sciences, 141, 1161-1165.

Saihu. (2019). Implementasi manajemen balanced scorecard di pondok pesantren Jam'iyyah Islamiyyah Tangerang Selatan. Mumtaz, 3(1), 1-22.

Setiawan, B. (2020). The anxiety of educational reform and innovation: bridging of top-down and bottom-up strategies within practice educational reform of curriculum in Indonesia. Studies in Philosophy of Science and Education, 1(2), 87-96.

Sofian, A. (2018). Internalization of character education in the SMPIT As-syifa boarding school. Jurnal Pendidikan Sains Sosial dan Kemanusian, 11(1), 47-62.

Sukmadinata, N. S. (2005). Landasan psikologi proses pendidikan. Remaja Rosdakarya.

Sulaiman, A., \& Wibowo, U. B. (2016). Implementasi sistem penjaminan mutu internal sebagai upaya meningkatkan mutu pendidikan di universitas Gadjah Mada. Jurnal Akuntabilitas Manajemen Pendidikan, 4(1), 17-16.

Thoha, M. (2018). Meningkatkan kemampuan membaca dan memahami kandungan Al- Qur'an surat Al-Hujurat ayat 13 dalam membina ukhuwah islamiyah melalui model pembelajaran kooperatif teknik penugasan. Humanis, 10(1), 65-74.

Umi, F., Sri, N., \& Lisdiana. (2018). The Adiwiyata school"s role in the development of character caring for the environment (A case study at the Junior High School 6 Tuban). Journal of Innovative Science education, 7(1), $54-62$.

Utomo, Y., \& Juul, E. (2017). Habituation model of implementing environmental education in elementary school. Jurnal Pendidikan Indonesia, 6(2), 206-212. 
Cooperative Learning Model in Tilawati Al Quran to Cultivate 25 Student Characters: Multi-Case Study https://doi.org/10.46627/silet.v1i3.53

Author (s) :

* Umar Jaeni (Corresponding Author)

Department of Management Education

Universitas Negeri Surabaya

Jl. Raya Kampus Unesa, Lidah Wetan, Kec. Lakarsantri, Surabaya, Indonesia

Email: umarjaeni16070976010@mhs.unesa.ac.id

Ismet Basuki

Universitas Negeri Surabaya

Jl. Raya Kampus Unesa, Lidah Wetan, Kec. Lakarsantri, Surabaya, Indonesia

Email: ismetbasuki@unesa.ac.id

Moedjiarto

Universitas Negeri Surabaya

Jl. Raya Kampus Unesa, Lidah Wetan, Kec. Lakarsantri, Surabaya, Indonesia

Email: moedjiarto@unesa.ac.id 